\title{
Effect of pre harvest application of boron and zinc on post harvest quality and vaselife of carnation
}

\author{
Likhitha Raj $^{{ }^{*}}$, Siddappa ${ }^{2}$, S. Varalakshmi ${ }^{3}$, H. M. Vikas ${ }^{4}$, C. H. Girjakumari ${ }^{5}$ \\ ${ }^{1,2,5}$ Department of Floriculture and Landscape Architecture, College of Horticulture University of Horticulture Sciences \\ Campus, Gandhi Krishi Vigyan Kendra, Bengaluru-560065 (Karnataka), INDIA \\ ${ }^{3}$ Department of Post Harvest Technology, College of Horticulture University of Horticulture Sciences Campus, \\ Gandhi Krishi Vigyan Kendra, Bengaluru-560065 (Karnataka), INDIA \\ ${ }^{4}$ College of Horticulture University of Horticulture Sciences Campus, Gandhi Krishi Vigyan Kendra, Bengaluru- \\ 560065 (Karnataka), INDIA \\ *Corresponding author. E-mail: likhitharajdolly@gmail.com
}

Received: May 30, 2015; Revised received: October 21, 2015; Accepted: February 18, 2016

\begin{abstract}
The study was conducted to determine the effect of pre harvest spray of micronutrients like boron, zinc and its combination on post harvest quality and vase life of carnation. Post harvest quality of flowers like flower stalk length $(65.61 \mathrm{~cm})$ was maximum in the plant treated with zinc $(0.3$ per cent), and calyx splitting $(3.12$ per cent) was minimum in the plants treated with boron $(0.1$ per cent). Flower diameter $(6.64 \mathrm{~cm})$ was highest with boron $(0.1$ per cent $)+$ zinc $(0.3$ per cent) treatment. Plants without micronutrient treatment produced poor quality flowers. Regarding vase life studies maximum water uptake and minimum transpiration loss from first day to sixteenth day was resulted in the flowers which are obtained from the plant treated with boron $(0.1$ per cent). The maximum fresh weight of the flower was noticed in combination of boron $(0.1$ per cent $)+$ zinc $(0.3$ per cent $)$ from first to sixteenth day. The foliar spray of boron ( 0.1 per cent) recorded maximum vase life (11.05 days). So the good quality of flowers can be improved by the foliar spray of zinc, calyx splitting can be controlled by boron foliar spray and vase life of the flower can be maintained by foliar spray of boron. It is confirmed that the foliar application of micronutrient is very much helpful for the improvement of post harvest quality and vase life of carnation.
\end{abstract}

Keywords: Carnation, Flower diameter, Micro nutrients, Vase life

\section{INTRODUCTION}

As one of the fourth important cut flowers in the world, carnation (Dianthus caryophyllus L.) not only plays important role in the garden, but also performs well in the florist trade, for that post harvest quality plays important role. Post harvest senescence is a major limitation to the marketing of many species of cut flowers. As carnation is very sensitive to ethylene and considerable effort has been devoted to develop post harvest treatments to extend the marketing period (Meng-Jen Wu et al., 1992).

Boron is an essential element for plant growth. Boron requirements differ widely among plant species and the concentration range between toxicity and deficiency is less for B than for any other nutrient. Boron availability to plants decreases with increasing soil $\mathrm{pH}$ and/or under drought conditions (Marschner, 1995). However the role of B in plant is still least well understood of all mineral nutrients. It is suggested that the primary effect of B deficiency appears to be disruption of the normal functioning of the apical meristems with change in membrane structure, cell wall synthesis, metabolisms of auxin, carbohydrate, ascorbate and
RNA, and lignification, phenol accumulation, and sucrose transport being secondary effects. Zinc is important as a component of enzymes for protein synthesis and energy production and maintains the structural integrity of biomembranes. Zinc plays an important role in seed development and zinc-deficient plants show delayed maturity. Zinc is required for the synthesis of auxin IAA and for carbohydrate metabolism, protein synthesis, internode elongation for stem growth and in pollen formation. $\mathrm{Zn}^{2+}$ ions at low concentration (0.01 ppm) slightly enhance the activity of tryptophan synthesis leading to biosynthesis of auxin (Chundawat, 1997).

Keeping in view the socio economic value of cut carnation, this study was designed to study the post harvest response of cut carnation flowers to foliar application of micronutrients such as boron and zinc. This experiment was planned to assess the effect of individual and combinations of micronutrients (boron + zinc) on post harvest quality and vaselife of carnation.

\section{MATERIALS AND METHODS}

This experiment was carried out in floriculture section, Regional Horticulture Research and Extension Centre 
(RHREC), University of Horticultural Sciences Campus, Gandhi Krishi Vignana Kendra (GKVK), Bangalore, to study the effect of foliar spray of boron, zinc and their interaction on post harvest study of carnation. Rooted tip cuttings were planted in naturally ventilated poly house with the spacing of $15 \mathrm{~cm} \times 15 \mathrm{~cm}$. This is planted after laying out the first layer of net and after 15 days of planting single pinching was carried out along all other intercultural operations like weeding, fertigation, disbudding, deshooting etc. There were four treatment, they are water spray $\left(\mathrm{N}_{0}\right), 0.1$ percent boron $\left(\mathrm{N}_{1}\right), 0.3$ percent zinc $\left(\mathrm{N}_{2}\right)$ and combinations of 0.1 percent boron and 0.3 percent zinc $\left(\mathrm{N}_{3}\right)$ were sprayed on the foliage by using hand operated sprayer at monthly interval starting from first month after planting for five times during the experimental period. This experiment was set up in a Randomized Complete Block Design (RCBD) in three replications. Various quality parameters of flowers were recorded at the time of harvest from five tagged plants. Cut flowers obtained from all the treatments were subjected to vase life studies. The flowers were harvested at tight bud stage and the uniform stalk length was maintained at $45 \mathrm{~cm}$ and a slant cut was given at the bottom end of the flower stalk. Cut flowers of carnation were placed in conical flasks containing $250 \mathrm{ml}$ of water. The vase life was expressed in terms of days from the date of harvest. The observation was recorded at daily interval until the flower petal fade and they were not suitable for vase. The difference between consecutive weights of bottle with solution (without flower stalk) represents the water uptake and it was expressed in grams. The difference between the consecutive weight of the bottle + solution + flower represents the water loss from the flowers for that particular period and expressed in grams per flower. The difference between the weight of the bottle + solution + flower stalk and weight of the bottle + solution gave the fresh weight of flower taken at sequential intervals and expressed in grams $(\mathrm{g})$ per flower.

\section{RESULTS AND DISCUSSION}

Flower quality parameters: Diameter of the flower and flower stalk length are the essential characters considered for grading of flowers (Table 1). Among foliar application of boron and zinc, the application of zinc $(0.3 \%)$ had a significant influence on flower stalk length. The maximum flower stalk length $(65.61 \mathrm{~cm})$ was noticed in treatment zinc $(0.3 \%)$, whereas, it was minimum in control $(56.75 \mathrm{~cm})$. This increased flower stalk length in carnation varieties due to better synthesis of more florigen and carbohydrates thereby inducing production of good vegetative growth. Foliar application of boron and zinc significantly increased the flower diameter. At the time of harvest, maximum flower diameter $(6.64 \mathrm{~cm})$ was recorded in combination of boron $(0.1 \%)+$ zinc $(0.3 \%)$, which was lowest in control $(6.10 \mathrm{~cm})$. The results, furthermore, showed that balanced feeding with micronutrients is an important factor for improving crop growth and production. In gladiolus and rose similar findings were recorded in flower quality by Halder et al. (2007) and Iftikhar et al. (2011) respectively.

Significant differences were found in boron and zinc with respect to calyx splitting. Minimum calyx splitting of 3.12 per cent was recorded in boron $(0.1 \%)$ spray. The maximum calyx splitting of 4.91 per cent was observed in treatment control. In general split occurs due to the increase in the volume of the petals within the calyx even after the attainment of full size of the calyx. The application of boron reduced the calyx splitting, this might be due to the fact that the optimum dose of boron being involved in the formation of cell wall, also gets tied up with the protein in the protoplasm so these gives strength to the calyx as observed by Karthikeyan et al. (2009) and (Jawaharlal et al., 2012) in carnation.

Post harvest studies: Longevity of cut flowers is related to the maintenance of fresh weight, good water uptake and low transpiration loss. The variations with respect to flower weight among varieties might also be the result of higher water and carbohydrates level in the flower. Water plays a very important role to maintain flower turgidity, freshness and petal orientation. Similarly, carbohydrates serve as energy source for growing bud, flower opening and longevity. In the present study, the effect of foliar spray of boron and zinc on water uptake was found to be significant (Table 2). Maximum water uptake $(7.00 \mathrm{~g}, 5.43 \mathrm{~g}, 7.83$ g, $5.57 \mathrm{~g}, 4.62 \mathrm{~g}, 4.57 \mathrm{~g}, 4.86 \mathrm{~g}, 3.70 \mathrm{~g}, 1.81 \mathrm{~g}, 0.95 \mathrm{~g}$, $0.81 \mathrm{~g}, 1.00 \mathrm{~g}, 0.76 \mathrm{~g}, 0.62 \mathrm{~g}, 0.91 \mathrm{~g}$ and $0.33 \mathrm{~g}$ ) was observed in treatment boron $(0.1 \%)$ from first day to sixteenth day, respectively and it was minimum in control (5.91 g, $4.19 \mathrm{~g}, 3.38 \mathrm{~g}, 3.43 \mathrm{~g}, 2.91 \mathrm{~g}, 2.81 \mathrm{~g}$, $2.52 \mathrm{~g}, 2.00 \mathrm{~g}, 1.00 \mathrm{~g}, 0.57 \mathrm{~g}, 0.48 \mathrm{~g}$ and $0.43 \mathrm{~g}$, respectively). Boron helps in the accumulation of simple carbohydrates and nitrogen compounds in plants as a

Table 1. Quality parameters of carnation flowers.

\begin{tabular}{llll}
\hline Varieties & Flower stalk length (cm) & Flower diameter (cm) & Calyx splitting (\%) \\
\hline $\mathrm{N}_{0}$ - Control & 56.75 & 6.10 & $4.91(10.20)$ \\
$\mathrm{N}_{1}$-Boron $(0.1 \%)$ & 60.26 & 6.35 & $3.12(7.47)$ \\
$\mathrm{N}_{2}$-Zinc $(0.3 \%)$ & 65.61 & 6.50 & $4.60(9.93)$ \\
$\mathrm{N}_{3}-$ Boron $(0.1 \%)+$ Zinc $(0.3 \%)$ & 60.05 & 6.64 & $4.42(9.73)$ \\
$\mathrm{S} . \mathrm{Em} \pm$ & 0.97 & 0.06 & $0.12(0.24)$ \\
$\mathrm{CD} @ 5 \%$ & 2.75 & 0.18 & $0.34(0.69)$ \\
\hline
\end{tabular}

Note: Values in the parenthesis are angular transformed values of three replications . 

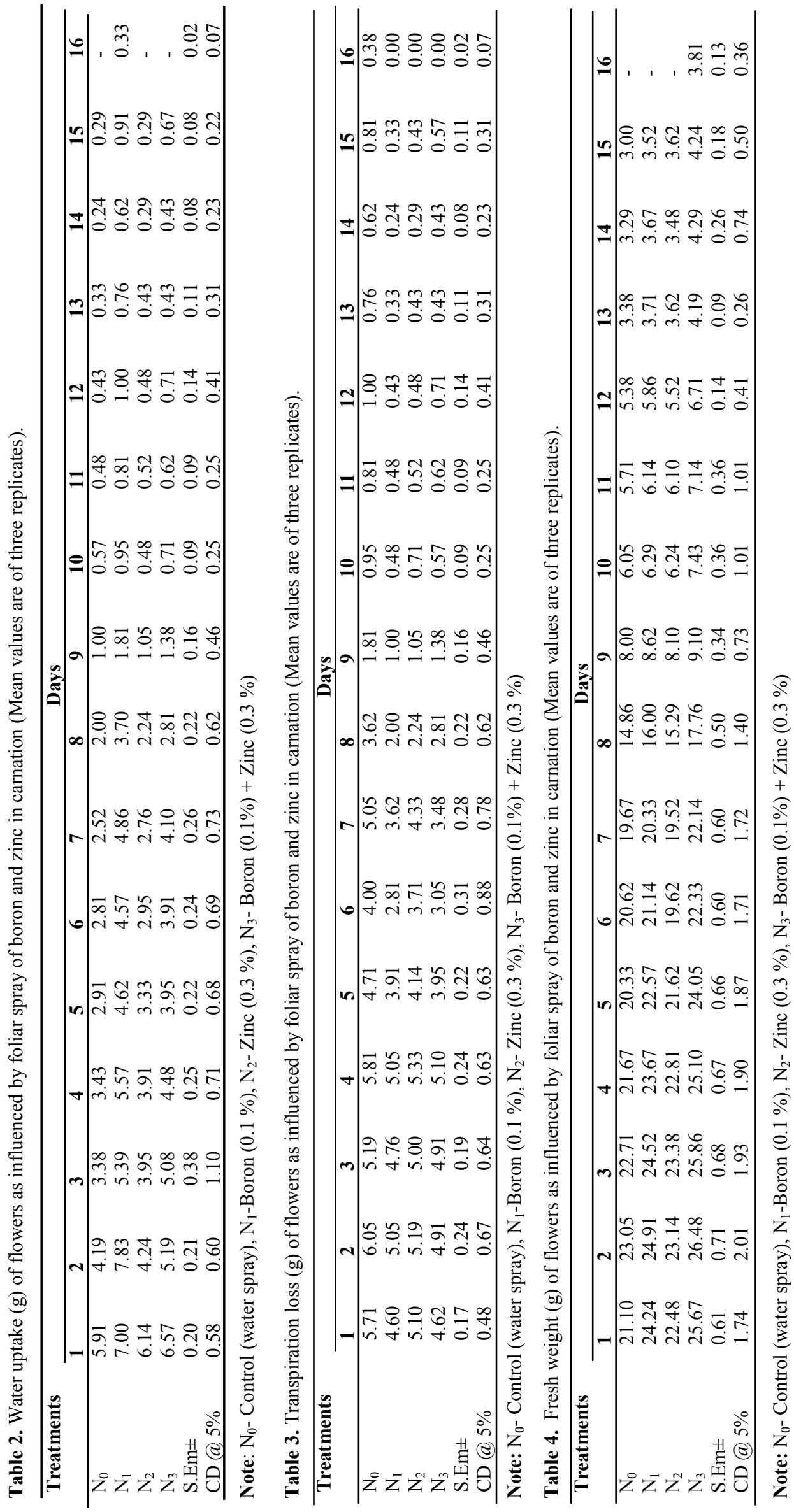
Table 5. Cumulative water uptake (g) and Vase life (days) of flower as influenced by foliar spray of boron and zinc in carnation (three replications).

\begin{tabular}{lll}
\hline Treatments & Cumulative water uptake & Vase life (days) \\
\hline $\mathrm{N}_{0}$ - Control & 30.98 & 10.10 \\
$\mathrm{~N}_{1}$ - Boron $(0.1 \%)$ & 47.60 & 11.05 \\
$\mathrm{~N}_{2}$ - Zinc $(0.3 \%)$ & 32.80 & 10.19 \\
$\mathrm{~N}_{3}$ - Boron $(0.1 \%)+$ Zinc $(0.3 \%)$ & 40.14 & 10.24 \\
$\mathrm{~S} . \mathrm{Em} \pm$ & 0.38 & 0.17 \\
$\mathrm{CD} @ 5 \%$ & 1.08 & 0.47 \\
\hline
\end{tabular}

prime component.

The influence of foliar spray of boron $(0.1 \%)$ and zinc $(0.3 \%)$ showed significant differences with respect to transpiration loss (Table 3). Application of boron (0.1 $\%)$ resulted in minimum transpiration loss $(4.60 \mathrm{~g}$, $5.05 \mathrm{~g}, 4.76$, g $5.05 \mathrm{~g}, 3.91 \mathrm{~g}, 2.81 \mathrm{~g}, 3.62 \mathrm{~g}, 2.00 \mathrm{~g}$, $1.00 \mathrm{~g}, 0.48 \mathrm{~g}, 0.48 \mathrm{~g}, 0.43 \mathrm{~g}, 0.33 \mathrm{~g}, 0.24 \mathrm{~g}$ and $0.33 \mathrm{~g}$, respectively) from first day to day sixteen, and in control transpiration loss was maximum $(5.71 \mathrm{~g}, 6.05 \mathrm{~g}, 5,19$ g, $5.81 \mathrm{~g}, 4.71 \mathrm{~g}, 4.00 \mathrm{~g}, 5.05 \mathrm{~g}, 3.62 \mathrm{~g}, 1.81 \mathrm{~g}, 0.95 \mathrm{~g}$, $0.81 \mathrm{~g}, 1.00 \mathrm{~g}, 0.76 \mathrm{~g}, 0.62 \mathrm{~g}, 0.81 \mathrm{~g}$ and $0.38 \mathrm{~g}$, respectively). This shows us that lower transpiration loss in boron treated plant is due to the strongest stems might be due to the contribution of boron in building up of cell wall, so lower transpiration loss and high water uptake is very useful and it helps to increase the vaselife of the flower on boron treated flowers as observed by Halder et al. (2007) in gladiolus.

Effect of foliar spray of boron and zinc was found significant with respect to fresh weight of the flower (Table 4). The effect of boron and zinc on fresh weight of the flower was found significant during the vase life studies of carnation. The maximum fresh weight of the flower $(25.67 \mathrm{~g}, 26.48 \mathrm{~g}, 25.86 \mathrm{~g}, 25.10 \mathrm{~g}, 24.05 \mathrm{~g}$, $22.33 \mathrm{~g}, 22.14 \mathrm{~g}, 17.76 \mathrm{~g}, 9.10 \mathrm{~g}, 7.43 \mathrm{~g}, 7.14 \mathrm{~g}, 6.71$ $\mathrm{g}, 4.19 \mathrm{~g}, 4.29 \mathrm{~g}, 4.24 \mathrm{~g}$ and $3.81 \mathrm{~g})$ was noticed in combination of boron $(0.1 \%)+$ zinc $(0.3 \%)$ from first to sixteenth day, respectively. Minimum $(21.10 \mathrm{~g}$, $23.05 \mathrm{~g}, 22.71 \mathrm{~g}, 21.67 \mathrm{~g}, 20.33 \mathrm{~g}, 20.62 \mathrm{~g}, 19.67 \mathrm{~g}$, $14.86 \mathrm{~g}, 8.00 \mathrm{~g}, 6.05 \mathrm{~g}, 5.11 \mathrm{~g}, 5.38 \mathrm{~g}, 3.38 \mathrm{~g}, 3.29 \mathrm{~g}$ and $3.00 \mathrm{~g}$ respectively) fresh weight was recorded in control. The combined effect of boron and zinc helped in the increased amount of micro nutrient levels in the leaves produced increased fresh weight of flower by involving in the photosynthesis, breakdown of IAA, auxins and protein synthesis. Similar findings were recorded in gladiolus, rose and in iris plant by Halder et al. (2007), Iftikhar et al. (2011) and Katiyar et al. (2012) respectively.

The data recorded on cumulative water uptake in different days during vase period are presented in (Table 5). Maximum cumulative water uptake (47.60 g) was observed in treatment boron $(0.1 \%)$ and it was lowest in control $(30.98 \mathrm{~g})$. The post harvest longevity of cut carnation flowers showed significant difference with regard to the influence of boron and zinc. The foliar spray of boron $(0.1 \%)$ to the plant recorded maximum (11.05 days) vase life. Whereas, it was lower (10.10 days) in control. Boron is involved in the maintenance of water balance and so high water uptake and more vase life because it will help in proper formation of cell wall as reported by Dale and Krystyna (1998) and Mahaboob et al. (2012) in rose.

\section{Conclusion}

It was concluded that the post harvest quality of the flower is very much dependent on the pre harvest treatments of the plant. It is concluded that, among four treatments, it is recommended use zinc 0.3 percent in the cultivation of carnation for the good quality flowers. Boron 0.1 percent is useful to prevent calyx splitting. Better vaselife of the flower can be maintained by foliar spray of boron to plant.

\section{REFERENCES}

Chundawat, B.S. (1997). Nutrient management in fruit crops. Agritech publishing academy, pp-256.

Dale, G.B. and Krystyna, M.L. (1998). Boron in plant structure and function. Ann. Rev. Plant Physiol. Plant Mol. Biol., 49: 481-500.

Halder, N.K., Siddiky, M.A., Ahmed, R., Sharifuzzaman, S. M. and Begum, R. A. (2007). Effect of boron and zinc fertilization on flower yield and quality of gladiolus in grey terrace soils of Bangladesh. J. Soil Nature, 1(3): 40 $-45$

Iftikhar, A., Aslam Khan, M., Qasim, M., Rashid, A. and Mahmood, R.A. (2011). Growth, yield and quality of Rosa hybrida L. as influenced by various micronutrients. Pakistan J. Agric. Sci., 47(1): 5-12.

Jawaharlal, M., Karthikeyan, S., Dhinesh, D. and Ganga, M. (2012). Boron role in quality carnation flower production (http:// floriculture today in/Boron-Role-in-Qualitycarnation.html)

Karthikeyan, S., Jawaharalal, S. and Ganga, M. (2009). Effect of boron on calyx spitting in carnation. J. Orn. Hort., 12 (4): 269-273.

Katiyar, P., Chaturvedi, O.P. and Dheerendra, K. (2012). Effect of foliar spray of zinc, calcium and boron on spike production of gladiolus cv. Euro vision. Hort Flora Res. Spectrum, 1(4): 334-338.

Mahaboob, S., Nematollah, E., Bahram, B., Ali, A.R. and Amir, H.K. (2012). Effect of boron and calcium on growth and quality of 'easy lover' cut rose. J. Plant Nutrition, 35: 1303-1313.

Marschner, H., (1995). Mineral nutrition of higher plants. Harcourt brace and company Pub., Academic Press, New York.

Meng-Jen Wu, Lorenzo, Z., Mikal, E., Saltveit and Michael, S.R. (1992). Alcohols and carnation senescence. Hort Science, 27(2):136-138. 